\title{
A Graduate Program, with Competitive Degree Candidates and Economics Education
}

\author{
James E. Curtis Jr. ${ }^{1}$ \\ ${ }^{1}$ The James Edward Curtis Jr Education Foundation, Washington, USA \\ Correspondence: James E. Curtis Jr., District of Columbia, Washington 20010, USA. Tel: 1-202-739-1962.
}

Received: July 13, 2018

Accepted: August 21, 2018

Online Published: August 29, 2018

doi: $10.20849 /$ jed.v2i 2.458

URL: https://doi.org/10.20849/jed.v2i2.458

\begin{abstract}
Curtis $\mathrm{Jr}$ (2018) presents a motivation and qualitative sample structure of higher education design. Curtis Jr (2018) describes the technical administrative processes of higher education completion using qualitative information concerning the methods of transfer, including transfer to the Education Foundation, IGRI, and JECJEF University.
\end{abstract}

Keywords: applied economics education, education entrepreneurship, religious studies

\section{Introduction}

Wikipedia (2013) suggests “... transfer is the anticipated" movement a student considers "between education providers and the related institutional processes supporting ... post-secondary learners who move ... completed coursework or training ... applicable to a degree." Transfers "between different education providers" and institutions "varied". Furthermore, “... Student mobility spans institutions and regions, differing policies and practices often extending ... degree completion by ... one semester. (General Accounting Office, National Center of Education Statistics, 2005)" “... By mid-2010, 2.2 million students ... experienced" higher education at "4,000 higher education institutions in 33 participating countries (European commission and European Union Lifelong Learning, 2007-2013)."

Effective description and completion of transferring to a graduate program is vital to the success of strong graduation candidates, i.e., Doctorate of Philosophy candidates, seeking regional and international association, and publications with academia, government and private sector researchers, leading research awards and successful higher education administration and faculty employment. This paper is a revision of The Economizing of Transcript Transcription Services for Graduate Programs with Competitive Degree Candidates, Education Foundation Preliminary Papers Series, written by James E Curtis, Jr in 2003, edited by James E Curtis, Jr. in 2013-2017. The paper is organized into the following, i. Certificates \& Degrees, ii. Certificates, Degrees, \& Requirements, iii. Course Catalog, Economics, iv. Course Catalog, General Studies, v. Course Catalog, Religious Studies, vi. transfer, vii. transfer of coursework completed and candidacy for degree graduation, and viii. references.

\section{Certificates \& Degrees, Succeeding at Education Foundation, Jecjef University}

Education Foundation/JECJEF University offers Certificates and Degrees upon successfully completion, including:

001 Department of Economics, IGRI

The Honorary Doctorate of Philosophy, Economics, H. Ph.D. 1.300000

002 Department of General Studies, IGRI

The Honorary Doctorate of Philosophy, Accountancy Economics History Laws, H. Ph.D. 1.300001

The Honorary Doctorate of Philosophy, Education, H. Ph.D., 1.300002

The Honorary Doctorate of Philosophy, Political Science, H. Ph.D., 1.300003

The Honorary Doctorate of Philosophy, Sociology, H. Ph.D., 1.300004

The Honorary Executive Doctorate of Laws, Religious Emphasis, H. D.L., 1.300005 
003 Department Of Religious Studies, IGRU

The Honorary Doctorate of Divinity, H.D.D., 1.300006

The Honorary Doctorate of Philosophy, Religious Studies, Ph.D., 1.300007

\section{Certificate \& Degrees, Requirements, Succeeding at Education Foundation, Jecjef University}

Education Foundation, JECJEF University offers Certificates and Degrees upon successfully completion, including:

Table 1. The Education Foundation, JECJEF University Degree requirements, 2003-2017

\begin{tabular}{|c|c|c|c|c|}
\hline 1.30000 Degree Requirements & $\begin{array}{c}1.30002 .34 .6 \\
\text { Doctorate of } \\
\text { Philosophy }\end{array}$ & $\begin{array}{l}\text { 1.30005 Executive } \\
\text { Doctorate of Laws }\end{array}$ & $\begin{array}{c}1.30007 \\
\text { Doctorate of } \\
\text { Divinity }\end{array}$ & $\begin{array}{c}1.30009 \text { Doctorate of } \\
\text { Philosophy, Religious Studies }\end{array}$ \\
\hline $\begin{array}{l}\text { 1.3013 Church Mosque } \\
\text { Temple Attendance }\end{array}$ & & & 10 years & 10 years \\
\hline $\begin{array}{l}1.3021 \text { Church Mosque } \\
\text { Temple Leadership }\end{array}$ & & & 2 years & 2 years \\
\hline $\begin{array}{l}1.3030 \text { Church Mosque } \\
\text { Temple Service }\end{array}$ & & & 4 years & 4 years \\
\hline 1.3040 College Degree & Master of Arts & Master of Arts & Master of Arts & Master of Arts \\
\hline 1.3050 Life Works & $1-5$ years & $1-5$ years & $10-20$ years & $5-10$ years \\
\hline 1.3060 Nonprofit Leadership & 1 year & 1 year & 2 years & 2 years \\
\hline 1.3070 Nonprofit Service & 2 years & 2 years & 4 years & 4 years \\
\hline 1.4000 & & & & $\mathrm{~S}, 1.4200$ or 1.4270 \\
\hline 1.4200 & & & & $\mathrm{~S}, 1.4000$ or 1.4270 \\
\hline \multicolumn{5}{|l|}{1.4210} \\
\hline \multicolumn{5}{|l|}{1.4220} \\
\hline 1.4230 & & $\mathrm{~S}$ & & \\
\hline \multicolumn{5}{|l|}{1.4240} \\
\hline \multicolumn{5}{|l|}{1.4250} \\
\hline 1.4260 & & & $\mathrm{~S}$ & \\
\hline 1.4270 & & & & $\mathrm{~S}, 1.4000$ or 1.4200 \\
\hline 1.4280 & & $\mathrm{~S}$ & & \\
\hline 1.4290 & & & & \\
\hline
\end{tabular}

\section{Course Catalog, Department of Economics, Education Foundation, Jecjef University}

The following economics courses are available in the Department of Economics through the Education Foundation, JECJEF University Internet Graduate Research Institute:

1.056 Economic Fundamentals, Principles of Economics, graphing, circular flow of goods \& services, production, demand, supply, equilibrium, social equilibrium, externalities, efficiency, taxes, tariffs, markets, national accounts, central banking, nonprofit organizations

1.067 Principles of Microeconomics, using equations and calculus, see 1.056

1.076 Intermediate Microeconomics, graphing micro theory including economic fundamentals, consumer labor intertemporal theory, firm production profit market theory

1.078 Advanced Microeconomics, using equations and calculus, see 1.076

1.088 Applied Statistics

1.188 Applied Econometrics 
1.200 Principles of Wealth Studies, Intermediate Wealth Studies, graphing social and ethnic groupings, laws \& economics, monetary economics, political economy, religion

1.278 Advanced Wealth Studies, using equations and calculus, see $1.200 \& 1.400$

\section{Course Catalog, Department of General Studies, Education Foundation, Jecjef University}

The following economics courses are available in the Department of General Studies through the Education Foundation, JECJEF University Internet Graduate Research Institute:

1.1891 Accounting

1.1891 Applied Mathematics

1.1892 Basic English

1.1892 Computer Lab, Data Analysis

1.1893 Economic Discrimination

1.1894 Economic History

1.1895 Extracurricular Activities

1.1896 Graduate Foundations in Economics

1.1897 Home Economics

1.1898 Independent Studies

1.1898 Seminar

1.1899 Thesis

\section{Course Catalog, Department of Religious Studiess Education Foundation, Jecjef University Course Catalog}

The following economics courses are available in the Department of Religious Studies through the Education Foundation, JECJEF University Internet Graduate Divinity University:

1.4000 The Enduring Faith Center

1.4201 Bible Commentary

1.4202 Comparative Theology

1.4203 Eldership Education

1.4210 Biblical Economics

1.4221 Biblical Entrepreneurship

1.4222 Church Development Corporations

1.4223 Jesus Christology Structures

1.4230 Genealogy of Jesus of the Holy Bible

1.4241 The Epistle of James

1.4242 James the Epistle for Jesus Christ

1.4250 James of the Holy Bible

1.4260 Musicology

1.4270 The Praise

1.4280 Religious protocol vs Grace in Jesus Christ

1.4290 Saint James the Apostle Congregations for Christ Jesus

\section{Transfering to Education Foundation, Jecjef University}

... transfer is the anticipated, movement a student considers, "between education providers and the related institutional processes supporting ... post-secondary learners who move ... completed coursework or training ... applicable to a degree." Transfers "between different education providers" and institutions "varied". "The application, applicability and articulation of prior course credits from one college or university to another culminates in a student's transfer and enrollment in a program of study" and "aspiring to complete a college credential. The assessment of prior learning and the articulation of credit offered to a prospective student varies 
based upon institutional practices and the enforcement of government policies" or "negotiated rules". "... Student mobility spans institutions and regions, differing policies and practices often extending ... degree completion by ... one semester (General Accounting Office and the National Center of Education Statistics, 2005)." ... By mid-2010, 2.2 million students ... experienced. higher education at " 4,000 higher education institutions in 33 participating countries (European commission and European Union Lifelong Learning, 2007-2013)." Education Foundation Preliminary Papers, with sincere gratitude to EF P.RA. James E Curtis, Jr and Wikipedia.org.

\section{References}

Carter, John, Steven Fenton, \& Tariq Modood. (1999). Ethnicity and Employment in Higher Education. London: Policy Studies Institute.

College Transfer. (2013). Retrieved from https://www.wikipedia.org/

Curtis Jr, James E. (2003, March 2018 Ed.). Correspondence with Higher Education Journals. Education Foundation Preliminary Papers.

Curtis Jr, James E. (2003, March 2018 Ed.). The Admissions Application to the Education Foundation. Education Foundation Preliminary Papers.

Curtis Jr, James E. (2003, March 2018 Ed.). The Application for Employment at the Education Foundation. Education Foundation Preliminary Papers.

Curtis Jr, James E. (2003, March 2018 Ed.). The Certification of Graduation from the Education Foundation. Education Foundation Preliminary Papers.

Curtis Jr, James E. (2003, March 2018 Ed.). The Checklist for Graduation from the Education Foundation. Education Foundation Preliminary Papers.

Curtis Jr, James E. (2015). JECJEF University A Philosophy of Educating \& The Origin of Credentials. Education Foundation Preliminary Papers.

Curtis Jr, James E. (2017 December 25,). Economics Education, excerpts from Economics Textbook Materials. Education Foundation Preliminary Papers.

Curtis Jr, James E. (2017). Designing JECJEF University. Education Foundation Preliminary Papers.

Curtis Jr, James E. (2017). The Honorary Doctorate of Education ... Education Foundation Preliminary Papers.

Hillman, Stuart J. (2014). Getting A Ph.D. in Economics. Philadelphia: University of Pennsylvania Press.

Johnstone, D. Bruce, \& Jason E. Lane. (2012). Universities and Colleges as Economic Drivers Measuring Higher Education's Role in Economic Development. Albany: State University of New York Press.

Lorette, Kristie. (2014). Running Successful Workshops and Seminars Plan, Promote and Present A Conference. Florida: Atlantic Publishing Group.

Pyrczaak, Fred. (2008). Evaluating Research in Academic Journals A Practical Guide to a Realistic Evaluation. A California Corporation. 


\section{Appendix A}

The coursework of James E Curtis, Jr, transferred to the Education Foundation/JECJEF University

\begin{tabular}{|c|c|c|c|c|c|c|c|}
\hline 01.500 Courses & $\begin{array}{c}01.501 \\
\text { Descriptions }\end{array}$ & 01.502 Institution of Transfer & 01.503 Quarters & $\begin{array}{l}01.505 \text { Transferred } \\
\text { to EF Course Grades }\end{array}$ & $\begin{array}{l}01.506 \text { Transferred to EF } \\
\text { Department }\end{array}$ & $\begin{array}{l}\quad 01.507 \\
\text { Transferred to } \\
\text { EF Title No. }\end{array}$ & $\begin{array}{l}01.508 \\
\text { Transferred to } \\
\text { EF Units }\end{array}$ \\
\hline $\begin{array}{l}01.11 \text { Classroom } \\
\text { studies }\end{array}$ & $\begin{array}{c}\text { i. Graduate } \\
\text { Studies classes }\end{array}$ & $\begin{array}{l}\text { I.0 Colleges \& Universities, including I.1 Ann } \\
\text { Arbor, MI I.2 Austin, TX I.3 Columbus, OH USA }\end{array}$ & $\begin{array}{l}\text { Summer 1997-Summer } \\
2003\end{array}$ & $\mathrm{~S}$ & $\begin{array}{l}\text { 0001. Economics, IGR.I } \\
\text { 0002. General Studies, IGRI }\end{array}$ & & \\
\hline $\begin{array}{l}02.21 \text { Independent } \\
\text { study }\end{array}$ & $\begin{array}{l}\text { i. Book study, } \\
\text { ii. Internet } \\
\text { research, iii. } \\
\text { multimedia } \\
\text { libraries }\end{array}$ & $\begin{array}{c}\text { I.0 James E Curtis Jr, self } \\
\text { I.1 4313 57th Ave, } 1 \\
\text { I.2 Bladensburg, MD 20710 USA } \\
\text { I.0 James E Curtis, Jr, self } \\
\text { I.3 } 524 \text { Kenyon St NW } 35 \\
\text { I.4 Washington, DC } 20010 \text { USA }\end{array}$ & $\begin{array}{c}\text { Autumn 2001, } \\
\text { Autumn 2002-Autumn } \\
2003 \\
\text { Winter 2010-Spring } \\
2018\end{array}$ & $\mathrm{~S}$ & $\begin{array}{l}\text { 0001. Economics, IGR.I } \\
\text { 0002. General Studies, IGRI }\end{array}$ & & \\
\hline $\begin{array}{l}03.10 \text { Multimedia, } \\
\text { preliminary } 03.11 \\
\text { Preliminary } \\
\text { papers }\end{array}$ & $\begin{array}{l}\text { i. EF, IGRI } \\
\text { ii. SSRN.com. }\end{array}$ & $\begin{array}{c}\text { I.0 James E Curtis Jr, self } \\
\text { I.1 4313 57th Ave, } 1 \\
\text { I.2 Bladensburg, MD 20710 USA } \\
\text { I.0 James E Curtis, Jr, self } \\
\text { I.3 } 524 \text { Kenyon St NW } 35 \\
\text { I.4 Washington, DC } 20010 \text { USA }\end{array}$ & $\begin{array}{l}\text { Spring 2001- Autumn } \\
2003 \\
\text { Winter 2010-Spring } \\
2018\end{array}$ & $\mathrm{~S}$ & $\begin{array}{l}\text { 0001. Economics, IGR.I } \\
\text { 0002. General Studies, IGRI }\end{array}$ & & \\
\hline $\begin{array}{l}04.50 \text { Field Work, } \\
\text { Thesis }\end{array}$ & $\begin{array}{l}\text { i. EF, IGRI } \\
\text { ii. SSRN.com. }\end{array}$ & $\begin{array}{c}\text { I.0 James E Curtis Jr, self } \\
\text { I.1 } 4313 \text { 57th Ave, } 1 \\
\text { I.2 Bladensburg, MD } 20710 \text { USA } \\
\text { I.0 James E Curtis, Jr, self } \\
\text { I.3 } 524 \text { Kenyon St NW } 35 \\
\text { I.4 Washington, DC 20010 USA }\end{array}$ & $\begin{array}{l}\text { Spring 2001-Autumn } \\
2003, \\
\text { Winter 2010-Spring } \\
2018\end{array}$ & $\mathrm{~S}$ & $\begin{array}{l}\text { 0001. Economics, IGR.I } \\
\text { 0002. General Studies, IGRI }\end{array}$ & & \\
\hline $\begin{array}{l}05.40 \text { Field Work, } \\
\text { Thesis }\end{array}$ & $\begin{array}{l}\text { i. EF, IGDU } \\
\text { ii. SSRN.com. }\end{array}$ & $\begin{array}{l}\text { I.0 James E Curtis Jr, self I.1 } 4313 \text { 57th Ave, } 1 \\
\text { I.2 Bladensburg, MD } 20710 \text { USA I.0 James E Curtis, Jr, self } \\
\text { I.3 } 524 \text { Kenyon St NW } 35 \text { I.4 Washington, DC } 20010 \text { USA }\end{array}$ & $\begin{array}{l}\text { Autumn 2002-Autumn } \\
\text { 2003, } \\
\text { Winter 2010-Spring } \\
2018\end{array}$ & $\mathrm{~S}$ & $\begin{array}{l}\text { 0003. Religious Studies, } \\
\text { IGDU }\end{array}$ & & \\
\hline
\end{tabular}




\section{Appendix B}

The honorary degrees of James E Curtis, Jr from Education Foundation, JECJEF University

\begin{tabular}{|c|c|c|c|c|}
\hline $\begin{array}{l}\text { 1.510 Degree Candidate } \\
\text { Name }\end{array}$ & 1.511 Degree Committee Members & $\begin{array}{l}1.512 \text { Degree, Date } \\
\text { Candidacy Completed }\end{array}$ & 1.513 Degree, Description & 1.514 Degree Evidence \\
\hline \multirow{3}{*}{ 1.9 James E Curtis, Jr } & *949 James E Curtis of Lisman, AL, & \multirow{3}{*}{ September 2017} & 9.1 Honorary Doctorate of & 9.1 Essays in Applied Labor Economics \\
\hline & *973 James E Curtis, Jr of the District of Columbia, & & Philosophy, & 9.2 Long Run Wealth Inequality \\
\hline & *971 revolved, Eccl 3:1-11, He 11:1, Matt 6:9-15 & & 9.2 Sociology & 9.3 Wealth Discrimination Theory \\
\hline 1.8 James E Curtis, Jr & $\begin{array}{l}\text { *949 James E Curtis of Lisman, AL, } \\
\text { *973 James E Curtis, Jr of the District of Columbia., } \\
\text { *971 revolved, Eccl 3:1-11, He 11:1, Matt 6:9-15 }\end{array}$ & January 2017 & $\begin{array}{l}\text { 8.1 Honorary Doctorate of } \\
\text { Philosophy, } \\
\text { 8.2 Political Science }\end{array}$ & $\begin{array}{c}8.1 \text { Institutional and Agency Effects on the Status of } \\
\text { Free Blacks: Synthesizing Asymmetrical Laws and } \\
\text { Social Conditions with Asymmetrical Economic } \\
\text { Outcomes }\end{array}$ \\
\hline \multirow{4}{*}{ 1.7 James E Curtis, Jr } & & \multirow{4}{*}{ January 2017} & & $\begin{array}{l}\text { 7.1 The Admissions Application to the Education } \\
\text { Foundation }\end{array}$ \\
\hline & *949 James E Curtis of Lisman, AL, & & $\begin{array}{c}\text { 7.1 Honorary Executive Master of } \\
\text { Arts, }\end{array}$ & $\begin{array}{l}\text { 7.2 The Application for Employment at the } \\
\text { Education Foundation }\end{array}$ \\
\hline & *971 revolved, Eccl 3:1-11, He 11:1, Matt 6:9-15 & & 7.2 Education Administration & $\begin{array}{l}\text { 7.3 The Certification of Graduation from the } \\
\text { Education Foundation }\end{array}$ \\
\hline & & & \multirow{7}{*}{$\begin{array}{l}\text { 6.1 Honorary Doctorate of } \\
\text { Philosophy, } \\
6.2 \text { Education }\end{array}$} & $\begin{array}{l}\text { 7.4 The Checklist for Graduation from the } \\
\text { Education Foundation }\end{array}$ \\
\hline \multirow{6}{*}{ 1.6 James E Curtis, Jr } & & \multirow{6}{*}{ January 2017} & & 6.1 Correspondence with Higher Education Journals \\
\hline & & & & 6.2 Designing JECJEF University \\
\hline & *949 James E Curtis of Lisman, AL, & & & 6.3 JECJEF University A Philosophy of Educating \\
\hline & *973 James E Curtis, Jr of the District of Columbia., & & & $\&$ The Origin of Credentials \\
\hline & \multirow[t]{2}{*}{ *971 revolved, Eccl 3:1-11, He 11:1, Matt 6:9-15 } & & & $\begin{array}{l}\text { 6.4 The Higher Education-Professional } \\
\text { Conferences", }\end{array}$ \\
\hline & & & & 6.5 The Honorary Doctorate of Education \\
\hline 1.5 James E Curtis, Jr & $\begin{array}{l}\text { *949 James E Curtis of Lisman, AL, } \\
\text { *973 James E Curtis, Jr of the District of Columbia., } \\
\text { *971 revolved, Eccl 3:1-11, He 11:1, Matt 6:9-15 }\end{array}$ & April 2014 & $\begin{array}{l}\text { 6.1 Honorary Executive Doctorate } \\
\text { of Laws }\end{array}$ & 5.1 Freedom Laws and The Economics of Ethnicity \\
\hline
\end{tabular}


The honorary degrees of James E Curtis, Jr from Education Foundation, JECJEF University (continued)

\begin{tabular}{|c|c|c|c|c|}
\hline $\begin{array}{l}\text { 1.510 Degree Candidate } \\
\text { Name }\end{array}$ & 1.511 Degree Committee Members & $\begin{array}{c}\text { 1.512 Degree, Date } \\
\text { Candidacy Completed }\end{array}$ & 1.513 Degree, Description & 1.514 Degree Evidence \\
\hline 1.4 James E Curtis, Jr & $\begin{array}{l}\text { *949 James E Curtis of Lisman, AL, } \\
\text { *973 James E Curtis, Jr of the District of Columbia., } \\
\text { *971 revolved, Eccl 3:1-11, He 11:1, Matt 6:9-15 }\end{array}$ & December 2013 & $\begin{array}{l}\text { 4.1 Honorary Doctorate of } \\
\text { Philosophy, } \\
\text { 4.2 Religious Studies }\end{array}$ & $\begin{array}{l}\text { 4.1 Biblical Economics and the Theology of Praise } \\
\text { 4.2 Biblical Entrepreneurship and Church } \\
\text { Development Corporations } \\
4.3 \text { Wealth and Faith }\end{array}$ \\
\hline 1.3 James E Curtis, Jr & $\begin{array}{l}\text { *949 James E Curtis of Lisman, AL, } \\
\text { *973 James E Curtis, Jr of the District of Columbia., } \\
\text { *971 revolved, Eccl 3:1-11, He 11:1, Matt 6:9-15 }\end{array}$ & December 2013 & $\begin{array}{l}\text { 3.1 Honorary Doctorate of } \\
\text { Divinity }\end{array}$ & $\begin{array}{l}\text { 3.0 The Enduring Faith Center, including } \\
\text { 3.1 Theological Business, } \\
\text { 3.3Theological Character, } \\
\text { 3.4 Theological Counseling, } \\
\text { 3.5 Theological Education, } \\
\text { 3.6 Theological Leadership }\end{array}$ \\
\hline 1.2 James E Curtis, Jr & $\begin{array}{l}\text { *949 James E Curtis of Lisman, AL, } \\
\text { *973 James E Curtis, Jr of the District of Columbia., } \\
\text { *971 revolved, Eccl 3:1-11, He 11:1, Matt 6:9-15 }\end{array}$ & December 2012 & $\begin{array}{l}\text { 2.1Honorary Doctorate of } \\
\text { Philosophy, } \\
\text { 2.2 Accountancy Economics } \\
\text { History Laws }\end{array}$ & $\begin{array}{l}\text { 2.1 A Theory of Wealth Accumulation } \\
\text { Considering Modern Net Savings Gradualism } \\
\text { The Impact of Unresolved Long Run } \\
\text { Differences in Wealth Accumulation } \\
\text { on the Annualized Net Savings in the USA } \\
\text { 1.0 Advanced Studies in Economics, including }\end{array}$ \\
\hline 1.1 James E Curtis, Jr & $\begin{array}{l}\text { *949 James E Curtis of Lisman, AL, } \\
\text { *973 James E Curtis, Jr of the District of Columbia., } \\
\text { *971 revolved, Eccl 3:1-11, He 11:1, Matt 6:9-15 }\end{array}$ & 2003 & $\begin{array}{l}\text { 1.1 Honorary Doctorate of } \\
\text { Philosophy, } \\
1.2 \text { Economics }\end{array}$ & $\begin{array}{c}\text { 1.1 Applied Econometrics, } \\
\text { 1.2 Applied Economic Theory, } \\
\text { 1.3 Applied Labor Economics, } \\
\text { 1.4 Economics Education, } \\
1.5 \text { Economic History }\end{array}$ \\
\hline
\end{tabular}

\section{Copyrights}

Copyright for this article is retained by the author(s), with first publication rights granted to the journal.

This is an open-access article distributed under the terms and conditions of the Creative Commons Attribution license (http://creativecommons.org/licenses/by/4.0/). 